\title{
The Unattainable Targets from Poverty Reduction Policy Strategy to Rural Grassroots: The Zanzibar Experience
}

\author{
Salum S. Ali \\ A PhD. Student, Perdana School of Science, Technology and Innovation Policy \\ Universiti Technologi Malaysia-UTM, Kuala Lumpur, Malaysia; Email: salhot78tz@yahoo.co.uk
}

Aini Suzana Ariffin

\author{
A Senior Lecturer, PhD. In STI Policy, Universiti Technologi Malaysia, Perdana School of Science \\ Technology and Innovation Policy, Kuala Lumpur, Malaysia; Email: aini.suzana@yahoo.com, ainisuzana@utm.my
}

\section{Doi:10.5901/mjss.2016.v7n2s1p273}

\section{Abstract}

Now a day several global initiatives like the Millennium Development Goals (MDGs) and follow up with Sustainable Development Goals (SDGs) have been put in place aimed at combating various global issues including extreme poverty face by Third world. The MDGs target one and two of the goal one aimed at overcoming the income poverty and hunger respectively, by 2015. Yet its achievement in many developing countries is not attained including Zanzibar. Thus, the study attempts to determine and elaborate on the mismatch between the established targets in poverty alleviation programs in Zanzibar particularly in MDGs target one and two of the goal one. The paper argued that despite the poverty reduction strategy introduced by the government of Zanzibar, the escalating rate of poverty in the country particularly at the rural grassroots is still very alarming. Within this context, this paper among other things examines the strategic failure and some challenges and barriers in reducing the rate of poverty in the country. It proceeds by showing some performance trends that realized since the establishment of the poverty reduction initiatives. The paper concludes that proper grassroots participation may assist and actively play significant role in the poverty reduction initiatives.

Keywords: MDGs, SDGs, Rural grassroots, Poverty reduction policy strategy, Grassroots participation, Zanzibar

\section{Introduction}

The World Bank launched the Poverty Reduction Strategy during 1999 aimed at helping developing countries on their development strategies and supports the pro-poor growth results. Since then the war against poverty is becoming a global concern and development agenda where both government and non-government actors are engaged on (Tiwar, 2008). One among the important initiative is the establishment of the Millennium Development Goals (MDGs) by the United Nations (UN) in the 2000 summit as declaration committed to all member countries - rich and poor - to establish a particular strategy among other things, to eradicate the extreme poverty, promote human dignity, equality and sustainable social development by 2015. Recently, in September 2015, the 193 countries of the UN General Assembly adopted the 2030 Development Agenda titled Transforming our world. There are 17 goals and 169 targets aimed at attaining a broad sustainable development by 2030. Amongst other goals are; end poverty in all its forms around the world; eradicate extreme hunger; achieve food security; improved child and mother nutrition; promote sustainable agricultural growth; ensure healthy lives and promote social well-being of all people around the world (Duke Center for International Development- DCID, 2015).

However, since the campaign against poverty reduction takes the lead the results to most of developing countries are not convincing (Dewachter and Molenaers, 2011). This study noticed that Zanzibar is among the poorest country in Africa and its population characterized by extremely poverty and most of it people living below the poverty line. The economy consists largely of the informal sector and rural economic activities with low productivity and informal jobs that reflects significant poverty and poor social security coverage among people (UNESCO, 2013). Thus, although there are so many efforts embarked on poverty reduction yet, the level of poverty among rural grassroots is still remaining as a great challenge.

This paper has attempted to address a number of issues pertaining to rural grassroots and poverty reduction policy strategy as main objective. In specific objectives the paper is intended to indicate the level of grassroots participation, the 
failure and some challenges and barriers which have been obstructing the intended effects not to happen in Zanzibar in relation to the MDGs. The paper used desk review methodology where secondary data is used, it analyses data and findings from a range of literature and national survey data. To have wider contemporary comments and experiences, the authors decide to conduct an interview with Dato' Dr. Lee Yee Cheong ${ }^{1}$.

The paper is organized into seven sections. Following a brief introduction, the Section two presents information about Zanzibar profile. The overview of the literature on conceptualizations of the key concepts and the general concern on the theme of the paper is given in Section three. The Section also offered information on Zanzibar economy and MDGs engagement. Section four presents the methodology of the study. Followed by section five that examines the strategic focus and its mismatch regarding to the MDGs. The section presents the findings on how the intended targets were not attained. This is followed by barrier and challenges that obstructing the intended effects in Section six. Conclusions and recommendation of the paper are provided in Section seven. The section among other things includes the comments on the experience of Dato' Dr. Lee Yee Cheong, in the MDGS and Sustainable development Goals of 2016-2030.

\section{About Zanzibar}

Zanzibar is a part of the United Republic of Tanzania since 1964 Union. Zanzibar is an archipelago of islands. It is an island nation that consists of two main islands, Unguja (usually referred to as Zanzibar) and Pemba, along with various smaller islands. The population is approximately 1.3 million people (Zanzibar Households Budget Survey -ZHBS, 2010). The language is called Kiswahili and is extensively spoken in east and central Africa.

The islands are found in the Indian Ocean at 40 kilometres off the east coast of Africa, and between 5 and 6 degrees south of the equator. The total land area is estimated to $2654 \mathrm{sq}$. Km by which Unguja covering $1666 \mathrm{sq}$. $\mathrm{Km}$ equivalent to 63 percent of total land and Pemba takes about $988 \mathrm{sq}$. Km equivalent to 37 percent (ZHBS, 2010). The Government of Zanzibar has autonomy over Zanzibar's internal issues, including sector and development policy. The current political administration of Zanzibar consists of a President, two Vice-Presidents, Cabinet of Ministers, a House of Representatives, and a Judiciary.
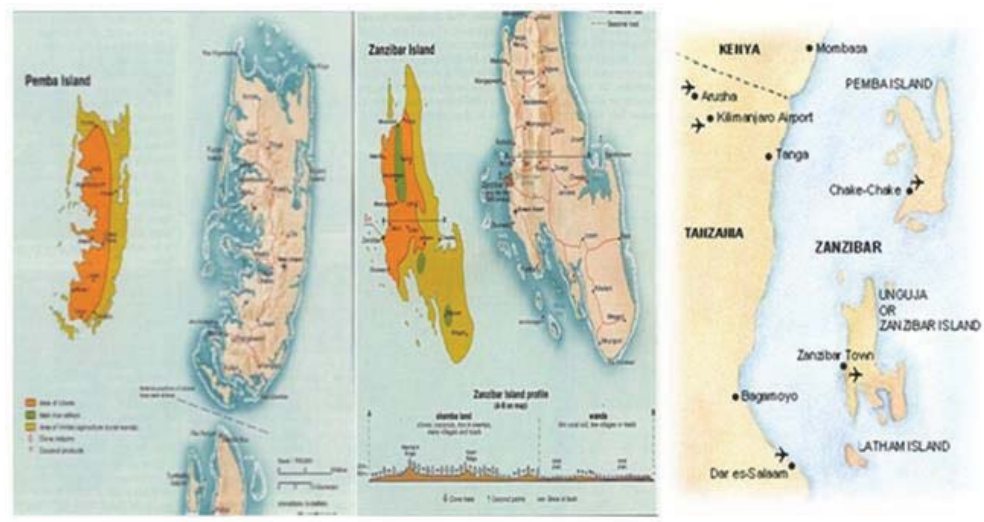

Zanzibar Islands.

\footnotetext{
${ }^{1}$ Among other profile, Dato' Dr. Lee Yee Cheong is the Malaysian Chairman of the Governing Council, International Science Technology and Innovation Centre for South-South Cooperation under UNESCO (ISTIC), Chairman of the Global Council Inter Academy Partnership (IAP) Science Education Program. Previously, he was Co-chair of Task Force Science, Technology and Innovation of the United Nations Millennium Project 2002-2005 and Vice Chairman of the UN Sustainable Development Solution Network (SDSN) Malaysia. In his excellence Dr. Lee Yee is member of the National Science and Research Council of Malaysia, member of Global Science Innovation Advisory Council (GSIAC) and member of the International Commission for Education for Sustainable Development Practice (http://www.alumni.adelaide.edu.au; http://www.istic-unesco.org/).
} 


\section{Literature Review}

\subsection{Conceptualization of the key concepts}

\subsubsection{Poverty reduction policy strategy}

It is a multidimensional platform that aimed at attempting to eradicate the causes and consequences of poverty with strategic focus on economic growth and improving conditions for the poor in term of power, capability and increases the livelihood opportunities (Handley et al, .2009). The process that adopted by the World Bank, IMF and the international community by creating special efforts and policy commitment for achieving poverty reduction (Bwalya et al,. 2004). The process mainly concerned to fight against poverty using several interventions in four priority thematic areas namely macroeconomic stability and fundamental policies to support economic growth, sectoral policies and programs to address the development of human capital, infrastructure development, and good governance to support sustainable social development (Cromwell et al, .2005). Thus, since its establishment the platform has become the key policy instrument that addressing the economic growth and poverty reduction strategy in many developing countries (Bwalya et al,. 2004). Therefore, the poverty reduction policy strategy is commonly regarded as a structural strategy for promoting economic growth that will permanently lift as many people as possible over a poverty line (Barder, 2009).

\subsubsection{Rural grassroots}

The term denotes as areas where a majority of its people is engaged in agriculture, including livestock, farming, forestry, and fisheries. In the broadest sense refers to the most basic level where people have the familiarity of their issues surrounding them (Smith, 2009). It can also be referred as the local community with sharing of the same characteristics of social life (Smit, Fressoli and Thomas, 2013). The rural grassroots are those most directly affected by development activities and indeed they are the key target of most development policies (Olofin, et al., 2011). Kukar (2008) describe rural grassroots as a locally based where people have the experience to identify and expose their social-economic. Most grassroots people in the developing countries are engaged in agricultural activities and their life characterised by poverty. Consequently, deprived in income opportunities, access to make decisions of their own matters and have limited access to basic goods and services (Gau et al., 2014).

\subsubsection{Participation}

Commonly referred as involvement of people in the decision making for their development ( Abiona\& Bello,2013). It is also termed as a process of empowering people to make decisions for their own development (Prato\& Longo, 2012). In this process the stakeholders should influence the decisions on the resources and share the control over development initiatives (World Bank, 1996: xi). In a practical sense, the term is perceived as public space to accommodate the processes in which individuals and groups have the opportunity in making decisions that affect them (Smith, 2003:5. Thus, participation is linked to local people working with their government to bring about lasting improvements to the places they live (Melbourne, 2004). At its broadest level of meaning, participation is nothing less than the basic fabric of social life where people set their strategies for survival at the local level (Bass et al.,1995).

\subsection{Major MDGs and poverty reduction concern to the developing countries}

The problem of poverty and how to reduce it remains as the most serious challenge in the global development debate and became as a key social agenda (Handley et al, .2009). Since the poverty reduction campaign began there is a healthy debate about how to achieve poverty reduction in developing Countries (Barder, 2009). For example, there is a serious concern about why Sub-Saharan Africa still remains as the poorest region in the global community and what can be done to realize the sustainable and pro-poor economic growth that will support poverty reduction and increases the peoples' livelihoods (Handley et al, .2009).

The developing countries have been suffering from extreme poverty for many decades. Thus, the international community calls for sustainable efforts and actions to create the global goals for economic growth and reducing poverty (OECD 2001). Consequently, in 1999, the World Bank and the International Monetary Fund (IMF) adopted a new set of processes to guide lending to some of the world's poorest countries to embark on the effort of economic growth and poverty reduction strategy (Levinsohn, 2003). As a result, in 2000 the United Nations (UN) summit sets the Millennium 
Development Goals (MDGS) as declaration committed to all member countries - rich and poor - to establish a particular strategy among other things, to eradicate the extreme poverty, promote human dignity, equality and sustainable social development by 2015. Since then Countries worldwide are making considerable efforts to achieve the MDGs aimed to dramatically reduce poverty and improve the peoples' livelihoods (WHO, 2005;2008). Thus, strategic interventions were typically designed by the respective countries in an attempt to achieve the intended goals and targets with the integrated efforts by the international community (Loewen, 2009). However, meeting the goals will require a substantial reorientation of development policies to focus on key issues of economic growth and social development ( Calestous and Lee Yee, 2005).

\subsection{Zanzibar and the Millennium Development Goals}

In 2000 summit the United Nations (UN) set the Millennium Development Goals as development committed agenda to all member countries. The declaration assert to establish a particular strategy among other things, to eradicate the extremely poverty, promote human dignity, equality and sustainable social development by 2015 (Handley et al,.2009). It is was suggested that achieving the goals required a strong strategy of development policies to focus on core drivers of economic growth that support social development and poverty reduction (Calestous and Lee Yee, 2005).

In achieving the MDGs goals and targets, the Zanzibar Government decided to align the goals with national strategic policy. The alignment was put in place within Zanzibar Vision 2020 and the formulation of Zanzibar Strategy for Growth and Reduction of Poverty (ZSGRP). All these strategies aspire to bring Zanzibar to a middle-income nation with convincing human and social sustainable development and free society of poverty. However, its success is still questionable. The discussion of the performance trend of the MDGs in Zanzibar particularly in target one and two of the goal one will be presented later in this paper.

\subsection{The Zanzibar economic profile}

Zanzibar is primarily characterized by service economy that takes 45 percent of the total economic growth (Revolutionary Government of Zanzibar, 2013). The Zanzibar economy is mainly depending on Tourism sector and Agriculture particularly Cloves production. The Zanzibar GDP at market price stands at USD 428.48 Million and the per capita income is estimated to be USD 557 as of 2009 compared with USD 1,500 from other developing countries (Ministry of Finance, 2013). The annual GDP growth rate in 2009 was 6.7 per cent. During 2012, Zanzibar economic growth measured by growth in real GDP was 7.0 percent compared to a growth rate of 6.7 percent in 2011. The rate of growth of agriculture sector declined to 1.3 in 2012 from 2.7 in 2011 (Ministry of Finance, 2013). During the year 2014 the economic growth recorded at 7.0 percent compared to 7.2 growth of 2013 and the per capita income is estimated to be USD 939 in 2014 from 866 as of 2013 ( Ministry of Finance,2015).

It is estimated that the service sector contributed to 44.7 percent in 2014 in general economic growth followed by agricultural sector by 27.9 percent in 2014 as declined from 30.4 to 2013 (Ministry of Finance, 2015). The data indicated that Zanzibar is among the poorest country in Africa and its population characterized by poverty and most of it living below the poverty line. The economy consists largely of the informal sector and rural economic activities with low productivity and informal jobs that reflects significant poverty and poor social security coverage among people (United Nations Educational, Scientific and Cultural Organization-UNESCO, 2013). The mismatch between economic growth and poverty reduction are not experienced in Zanzibar alone. For example, it has been the fact that while India is a powerful emerging economy that has exhibited impressive growth since 1990, it is also home to more than 400 million people living below the global poverty line (Patel, 2013).

\section{Methodology}

This study used review method and interview to assess and examine the performance of the MDGs and the Poverty reduction initiatives at the Zanzibar grassroots areas. The researchers conducted an extensive review of the current literatures, national survey data and relevant government reports. Researchers decided to use national survey data because of its wider coverage and representativeness national wide. On the other hand, review of vast literature was used to further the research on the current observations and existing facts towards the MDGs and poverty reduction issues. To ensure the contemporary information is covered by the study, the researchers employed interview method with the senior and experienced player in the field. This was very important to explore the current facts, experiences and valuable opinions. 


\section{Results and Analysis}

\subsection{The strategic focus and the mismatch}

Since 2000, the Revolutionary Government of Zanzibar (RGoZ) has implementing several strategies for improving economic growth and social development. Zanzibar's Strategy for Growth and Reduction of Poverty (ZSGRP I \& II) widely referred as MKUZA ${ }^{2}$ I\&Il as a broad national Policy was introduced between 2005 and 2010. Previously, there was a Zanzibar Poverty Reduction Program (ZPRP) starting from 2002. MKUZA II is a successor of MKUZA I whose implementation came to an end in 2010. Both The MKUZA I\& II aimed at ensuring the achievement of sustainable propoor growth that support the reduction of both income and non-income poverty among the poor's Zanzibaris. To ensure the strategy is meeting the national and international standard, it was designed in line with Zanzibar Development Vision 2020 and the MDGs. The formulation and implementation of both strategies are still in a debate concerning its performance. For instance, the View of the People Report conducted in Zanzibar (2009) indicated that there is a deep concern about people's awareness on policies relating to the National Strategy for Growth and Reduction of Poverty. Thus, the report added there is an urgent need to provide more information, to improve people's inclusiveness and the dissemination of important information. The main setback observed in this report is the poor people involvement and poor information dissemination.

Many strategies that initiated for poverty reduction in most of the developing countries, Zanzibar in particular, are experienced failure. This is due to fact that most of the schemes are not participatory and hence lack the people priorities particularly at the grassroots level. It is observed that the development is largely depends on local ownership and innovative, it cannot be achieved and sustained out of their ownership and champions (Calestous, and Lee Yee, 2005). In addition, Worton (2009) observed that people at the grassroots level, which most of them living in poverty have a better position to contribute in multi-sectoral poverty reduction initiative; thus, must have a space to participate in developing development initiatives that have impact to their social well-being. Yet they are often absent and voiceless. He suggests that to attain poverty reduction initiatives, there should be a diverse, participatory mechanism which may support participation space for people involvement to match the specific needs of individuals and the society. For example, the observation shows that in Nigeria, despite the government introduced poverty reduction schemes to support pro-poor growth and poverty reduction, yet the rate of poverty in the country is still increasing and the effort is very disappointed and alarming (Abubakar, 2012).

In Zanzibar, the first strategy has set the target to reduce poverty particular to the general population where most of them living at rural areas. The strategy aimed at reducing the amount of people living below the basic needs poverty from 49 percent in 2005 to 25 percent by 2010 . Secondly, is to reduce the proportion of people living below the food poverty line from 13 percent in 2005 to 10 percent by 2010.

The current situation shows that rural poverty it seems as tragedy. The Zanzibar House Hold Survey of 2010 shows there is only marginal declined of the food poverty incidence. The report also indicates that the population with below the basic needs poverty line has declined only from 49.1 to 44.4 percent in 2010 as shown in table 1 below. The further observation indicates that poverty incidence is consistently higher. Besides, the distribution of per capital expenditure is increased significantly and thus, the inequality ration between poor and rich is noticed very higher where by the Gini coefficient rising from 0.28 to 0.30 in 2010 .

Table 1: Poverty and Inequality trends in Zanzibar (The income is in Tanzania Shillings).

\begin{tabular}{|c|c|c|c|c|c|c|}
\hline Poverty and Inequality & \multicolumn{3}{|c|}{200405} & \multicolumn{3}{|c|}{2009110} \\
\hline \begin{tabular}{|l|l} 
& (Head count refo) Percentene of populaion below he food poverty ine
\end{tabular} & Rural & Uban & Total & Rural & Urban & Total \\
\hline (Head count rafo) Percertage of coovulaton beb whe basc needs poverty ine & 54.6 & 40.5 & 49.1 & 50.7 & 35.9 & 44.4 \\
\hline Gri Coefficent & 0.26 & 0.3 & 0.28 & 028 & 0.31 & 0.3 \\
\hline \multicolumn{7}{|l|}{ Household Income } \\
\hline Mean per capta Household annualy income & 330,814 & 500,137 & 397,494 & 409,826 & 581,773 & 483,520 \\
\hline Percentage ofagrial turalfishing share ofin $\infty$ ne & 20.3 & 2.8 & 11.6 & 21.4 & 2.8 & 13.2 \\
\hline
\end{tabular}

Source: Zanzibar Households Budget Survey (ZHBS), 2010.

\footnotetext{
2 Known as in Swahili version as Mkakati wa Kukuza Uchumi na Kuondoa Umasikini Zanzibar
} 
The observation affirm that Zanzibar still remains one of the poorest countries in Africa and the world at large with more than one third of its population living below both food and basic needs poverty line (HBS, 2010). The report also indicating that most of the income of the rural people is very weak and low as shown in the table 2 below.

Table 2: Households main source of cash income in percentage distribution in Zanzibar

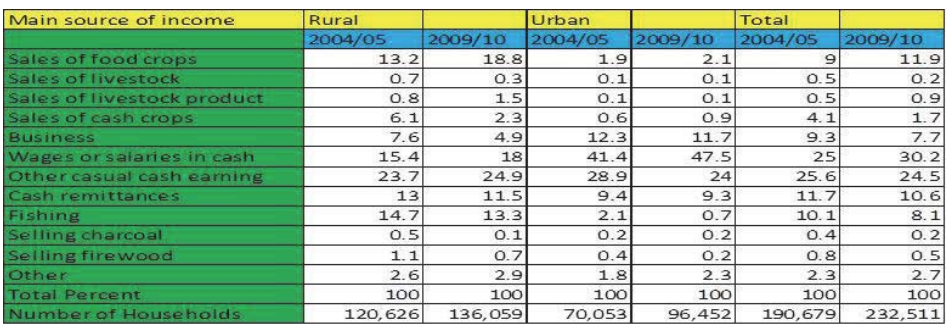

Zanzibar Households Budget Survey (ZHBS),2010

Further observation shows that the incidence of basic need poverty is still remaining higher representing 44 percent of the Zanzibaris did not able to fulfil their daily social needs (HBS, 2010). Although government and non-government actors embarked several efforts still the food poverty, basic needs poverty and poverty gap is very critical in Zanzibar as seen in the table 3 and chart 1 below. The situation at the grassroots level is very worst compared to people living at town areas. Consequently, the grassroots people suffered much from extremely poverty compared to urban.

Table 3: Zanzibar Poverty Headcount Ratio and Poverty Gap by Area

\begin{tabular}{|l|c|c|c|}
\hline \multirow{2}{*}{ Food Poverty Headcount } & \multicolumn{3}{|c|}{$\mathbf{2 0 0 9 / 1 0}$} \\
\cline { 2 - 4 } & Rural\% & Urban $\%$ & Total\% \\
\hline Food Poverty Gap & 16.76 & 8.09 & 13.04 \\
\hline Basic Needs Poverty Headcount & 3.35 & 1.31 & 2.48 \\
\hline Basic Needs Poverty Gap & 50.74 & 35.97 & 44.41 \\
\hline
\end{tabular}

Source: ZHBS,2010

Chart 1: Percentage of Population below Basic Needs Poverty Line in Zanzibar Rural and Urban
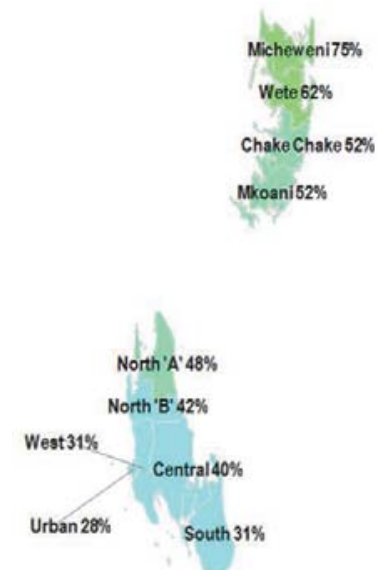

Source: ZHBS, 2010 
It has been observed that the poor performance of the poverty reduction strategy is the main reason for poverty persistence particular at rural areas. It is further claimed that the shift from the Zanzibar Poverty Reduction Program of 2002 to the Zanzibar Strategy for Growth and Reduction of Poverty of both 2005 and 2010 among other reason was the lack of wider participatory approach thus, the reduction of poverty initiatives were too far from the reality (MKUZA ${ }^{3}$ Studies, 2010). The same experience shows that the new growth strategy and poverty reduction initiative are a predicament phenomenon and the successor strategy seem to intrinsic the same syndrome.

Another study also claimed that many people are not aware in the most of the good policies laid down to implement MKUZA as growth and poverty reduction strategy and hence they remain on the shelves of expert (View of the People Report, 2009). The critical question under this circumstance is that are MKUZA relating policies and Programs are participative or not.

Mismatch between the pro-poor economic growth strategy and poverty reduction is another point of discussion. According to Mashindano (2009) there is a mismatch between the economic growth and continuing poverty reduction initiatives in Tanzania, Zanzibar in particular. He observed that while the rate of economic growth has been recorded with positive change over decades, yet the rate of poverty reduction does not match with the proportional and the experienced growth as the incidence of poverty has declined only 1.3 percent from 38.7 in 2000 to 37.4 percent in 2010 . The main issue observed from this failure, among other factors, is the poor people's involvement in most of the policies and programs, particularly to the grassroots rural where the majority live in extreme poverty. People at this level lack proper participation space because of poor and weak supportive institutions and infrastructure.

In other hand, the study conducted to examine foreign aid effectiveness in the efforts of poverty reduction in rural Tanzania found that the program was, on the whole, a failure. One of the main reasons is that there is a weak and poor people's participation to initiate program targets and objectives, consequently, most of the development plans and strategies failed to represent the people demand and requirements at their locality. The study further claimed that failure to acknowledge the practice of participatory decision-making at the grassroots level in the development process, marginalized the people's power to bring their own development and prosperity, especially rural women which are the majority among the rural poor population. As a result the incidence of poverty between urban and rural is growing because of the poor strategies that in placed for the rural grassroots and failure to institutionalize the participatory process as shown in chart 2 below.

Chart 2: Poverty Incidence between Rural and Urban areas in Zanzibar

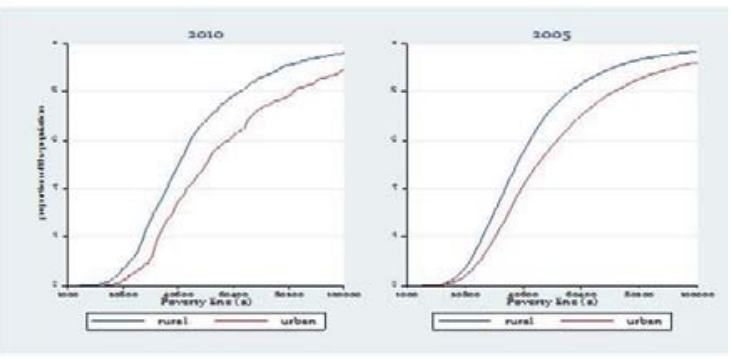

Source: ZHBS,2010

5.2 Challenges and Barriers that hindering the intended effects not to be attained in Zanzibar Poverty Reduction Initiatives and the MDGs

MKUZA studies of 2010 have mentioned several challenges and barriers that hindered the success of the National Poverty Reduction Policy Strategy as in line with MDGs as follows:-

- Poor people participation particularly rural grassroots on both formulation and execution of the strategy

- Poor and weak institutional setting that support the implementation process

- Poor public policy from the respective sector that support the implementation of the strategy

- Ambiguous target and strategies

${ }^{3}$ Known as in Swahili version as Mkakati wa Kukuza Uchumi na Kuondoa Umasikini Zanzibar 
- Too much expectation and ambitions

- Top up approach from the poverty strategy

- Poor resources mobilization

- Poor budget allocation

- Weak growth strategies

- Poor public-private partnership

In the context of Poverty reduction initiatives and the performance trend of MDGs in Zanzibar, the achievement of the intended goals remaining as serious challenge particularly on overcoming the poverty and hunger among rural grassroots. Thus, the new outlook is required particularly in the area of rural grassroots participation in the process of developing the strategies for their social development. The table 4 below provides the summary of the MDGs achievement status in Zanzibar by 2013.

Table 4: The trends of some selected indicators of the MDGs in Zanzibar to 2013

\begin{tabular}{|c|c|c|c|c|c|c|}
\hline MDG & Indicator & $\begin{array}{l}\text { Baseline- } \\
1990\end{array}$ & 2010 Status & $\begin{array}{l}\text { Current } \\
\text { status - } 2013\end{array}$ & $\begin{array}{l}2015 \\
\text { Target }\end{array}$ & $\begin{array}{l}\text { Progress at a } \\
\text { Glance }\end{array}$ \\
\hline \multirow[t]{2}{*}{$\begin{array}{l}\text { 1. Eradicate extreme } \\
\text { poverty and hunger }\end{array}$} & $\begin{array}{l}\text { 1.1 Proportion of population below \$1, PPP } \\
\text { (based on national income poverty line) }\end{array}$ & 61 & 44.41 & $44.41(2010)$ & 30.5 & Not achievable \\
\hline & $\begin{array}{l}\text { 1.1 Proportion of population below \$1, PPP } \\
\text { (based on national food poverty line) }\end{array}$ & 25 & 13.04 & $13.04(2010)$ & 12.5 & Achievable \\
\hline $\begin{array}{l}\text { 2. Achieve universal primary } \\
\text { education }\end{array}$ & $\begin{array}{l}2.1 \text { Net enrolment ratio in primary } \\
\text { education }(\%)\end{array}$ & 50.9 & 81.5 & 83.6 & 100 & Not achievable \\
\hline $\begin{array}{l}\text { 3. Promote gender equality } \\
\text { and empower women }\end{array}$ & $\begin{array}{l}\text { 3.4 Proportion of women among members } \\
\text { of Parliament (\%) }\end{array}$ & & 30 & $27(2013)$ & 50 & Not achievable \\
\hline 4. Reduce child mortality & $\begin{array}{l}4.3 \text { Proportion of children vaccinated } \\
\text { against measles }\end{array}$ & & $85(2010)$ & $90.8(2012)$ & 100 & $\begin{array}{l}\text { Achievement } \\
\text { probable }\end{array}$ \\
\hline \multirow[t]{2}{*}{ 5. Improve maternal health } & $\begin{array}{l}5.1 \text { Maternal Mortality Ratio (per 100,000 } \\
\text { live births) }\end{array}$ & 377 (1998) & 279 & 221.4 (2012) & 170 & Not achievable \\
\hline & $\begin{array}{l}\text { 5.2 Proportion of births attended by skilled } \\
\text { health personnel (\%) }\end{array}$ & & 44.7 (2008) & $53.7(2010)$ & 90 & Not achievable \\
\hline \multirow[t]{2}{*}{$\begin{array}{l}\text { 6. Combat HIVIAIDS, } \\
\text { malaria and other diseases }\end{array}$} & 6.1 HIV prevalence, $15-24$ years & 6 & $2.5(2008)$ & $0.5(2011)$ & $<0.6$ & Achieved \\
\hline & $\begin{array}{l}\text { 7.9 Proportion of people with access to } \\
\text { improved sanitation (Rural/Urban) }\end{array}$ & $26 / 52$ & $51 / 75(2005)$ & $67 / 85(77)$ & & Achievable \\
\hline
\end{tabular}

Source: Zanzibar Planning Commission, 2014

The MDGs among other things, pledged to reduce the proportion of people living below poverty line by 2015 from 28.3 percent to 14.2 percent. The goals also plea for reducing the proportion of people who suffering from food poverty between by 2015. However, the attainment is remaining as policy concern. The Zanzibar MDGs review of 2014 indicating that there is slow progress in turning the tide against poverty. The above observation show that the eradicating of extreme poverty and hunger is still remaining as a challenge. The result indicates that the eradication of proportion of people living below the poverty line is not achieved as indicated in table 4.

The Zanzibar MDGs report also indicating that too few people are benefitting from the current economic growth that has been experienced in recent years and inequalities are growing. The ZHBS (2010) report shows that there is a huge gap between rural and urban areas. The number of people living below the food poverty line is recorded 17 percent at rural area while urban areas recorded only 8.1percent. In other hand, the number of people living below the basic needs poverty line in rural areas is recorded 50.7 percent compared with 35.9 percent in urban areas as shown in table 5 below

Table 5: Basic and food poverty ratio in Zanzibar

\begin{tabular}{|l|c|c|c|}
\hline Poverty and Inequality & \multicolumn{3}{|c|}{$2009 / 2010$} \\
\hline Population below the food poverty line & Rural\% & Urban\% & Total\% \\
\hline Population below the basic needs poverty line & 17 & 8.1 & 13 \\
\hline Gini Coefficient & 50.7 & 35.9 & 44.4 \\
\hline
\end{tabular}

Source: ZHBS, 2010 


\section{Conclusion and Recommendations}

According to Prammer \& Martinuzzi (2013) UN among others, provides the following intervention for post Millennium Development Goals to help the poverty reduction initiatives.

- Inclusive and unbiased economic growth (UN 2012; para 4)

- Energetic engagement of the general population and the private sectors, increase public-private partnerships, engage in responsive business practices (e.g. UN Global Compact) (UN 2012; para 46)

- Emphases the importance of the involvement of local peoples (UN 2012; para 46)

Zanzibar as among developing country and Island country where most of its population is poor rural grassroots needs strategic focus and serious attention to combat poverty among its people. Zanzibar has only about 1.3 million populations, thus, if Government engaged seriously on participatory approach of its people in poverty reduction initiatives, the much success will be realized. It is suggested that Poverty reduction initiative would only achieved by offering broad, participatory process and people ownership of the development process (Worton, 2009). Thus, another dimension to inclusive development efforts is needed to ensure proper people's contributions to their local areas social development.

According to Dato' (Dr) Ir. Lee Yee Cheong (2015) on interview discussion the ending MDGs was facing the following shortfalls that contributed to the less achievement to most developing countries:

- The MDGs (2000-2015) lack the action plan for its implementation.

- The process of the MDGs was mainly dominated by developed countries (G.7).

- The fund to help its implementation was not properly provided.

- Many goals of the MDGs were not clear.

- Government from developing countries is mostly depending on resources from the World Bank (WB), United Nation (UN) and International Monitory Fund (IMF).

- There is also poor resource allocation from respective countries.

- Poor commitment and government will in the developing countries.

- Poor mind set and strategic focus on development context in the developing countries.

- Developing countries, African countries in particular, always believed in aid.

- Most public policy from developing countries not fevers the poor.

- Frequent changing of policy and priority in the developing countries.

In other hand, in the new Sustainable Development Goals (2016-2030) Dato' (Dr) Ir. Lee Yee Cheong (2015) in interview dialogue claimed that the SDGs process was inclusive means that there was a wider participations among the stakeholders. He also pointed out that the SDGs goals is well disintegrated with an action plan to allow a clear implementation and monitoring

However, it has been argued that the SDGs has too much of a good thing with 17 goals and 169 accompanying targets, it is next to impossible to set priorities, measure results or hold anyone accountable (Duke Center for International Development- DCID, 2015). Thus, it is suggested that if the international community truly want to help poor nations develop and reduce poverty, the actors should redouble efforts selectively and strategically at the international and the country level, particularly of the country's leadership, citizen's ownership and to focus only on crucial goals (DCID, 2015).

It is also suggested that the diversity of opinions, cross-disciplinary approaches, inclusiveness and openness can strengthen the poverty reduction efforts and improve public trust towards established goals ( Calestous, and Lee Yee, 2005). In other hand, private sector participation in poverty reduction initiatives is significant and, without it, the sustainable development would be not likely, thus, a sound participation and engagement of the private sector may also be viewed as another way forward of increasing performance on implementing post MDGs. As current practice, the attempt of involving the private sector in the development debate has been largely paralyzed as a result; there is a limited contribution to the MDGs (Prammer, \& Martinuzzi, 2013). It has been further argued that the inclusiveness of both public and private actors play a significant role in attaining international and national resulting policies for development( Calestous, and Lee Yee, 2005). Thus, building institutional capacity, participatory space, advice mechanism and public trust will enable the development process to attain its intended results.

In more specifically, to ensure the developing countries, Africa in particular, achieve the SDGs Dato' (Dr) Ir. Lee Yee Cheong (2015) suggested the following:

- Developing countries to have their own development model, framework and approaches and not to believe much in western thinking of development strategies.

- African people and government to change their mindset and put their future development on their own hand. 
- African government should put special efforts on SMEs development.

- African government should create, among other things, the affirmative program for the poor.

- Public policy should focus more to the poor people.

- African countries should think more strategically and to look for other development opportunities.

- African should promote their own value and develop the culture of serving and control the consumption, particularly to the youth.

- Promote gender equality.

- African diaspora to provide constructive ideas rather than criticism.

- Increase relation between South-South countries.

UN (2013) pointed out that people want a global development agenda, backed by national policy action that can empower them to realize the future they want. Therefore, Developing countries should put their efforts seriously in war against poverty and use the resources very wisely. The Government should have a strong commitment and the leadership should show their will on it.

\section{References}

Abiona, A and Bello, W (2013) Grassroots Participation in Decision-Making Process and Development Programmes as Correlate of Sustainability of Community Development Programmes in Nigeria doi:10.5539/jsd.v6n3p47 URL: http://dx.doi.org/10.5539/jsd. v6n3p47

Abubakar, B (2012) : Poverty alleviation through strategic public library services in Nigeria in the 21st century: a model, International Federation of Library Associations and Institutions 39(1) 4-14, DOI: 10.1177/0340035212472283, ifla.sagepub.com

Bwalya, E et al,(2004) Poverty reduction strategy processes in Malawi and Zambia, Chr. Michelsen Institute Development Studies and Human Rights

Barder, O (2009) What Is Poverty Reduction?, Center for Global Development- CGD, http://www.cgdev.org/

Bass, S et al. (1995)Participation in Strategies for Sustainable Development Environmental Planning Group International Institute for Environment and Development 3 Endsleigh Street, London WC1H ODD, UK Environmental Planning Issues No. 7.

Cheong, Lee Yee (2015): Interview session, October, 2015, Kual Lumpur, Malaysia.

Cromwell, E et al, (2005) Poverty Reduction Strategies and the Rural Productive Sectors: Insights from Malawi, Nicaragua and Vietnam , Overseas Development Institute 111 Westminster Bridge Road London SE1 7DJ UK

Calestous, J and Lee Yee, C (2005) : Innovation : Applying Knowledge in Development, Achieving the Millennium Development Goals, UNDP Millennium Project, UK and USA

Dewachter,S and Molenaers N (2011) Who Takes a Seat at the Pro-Poor Table? Civil Society Participation in the Honduran Poverty Reduction Strategy, Latin American Research Review, Vol. 46, No. 3. the Latin American Studies Association.

Handley et al, (2009) Poverty and poverty reduction in sub-Saharan Africa: An overview of the issues 2009. Overseas Development Institute 111 Westminster Bridge Road London SE1 7JD

http://www.alumni.adelaide.edu.au

http://www.istic-unesco.org.

Gau, R et al (2014) Community-Based Initiatives and Poverty Alleviation in Subsistence Marketplaces, Journal of Macro marketing 2014, Vol. 34(2) 160-170, sagepub.com/journals Permissions.nav DOI: 10.1177/0276146714522265 jmk.sagepub.com

Kukari, A (2008)Include grassroots in dialogue, News Digital Media, News Limited Feb 20, 2008

Levinsohn, J (2003) The World Bank's Poverty Reduction Strategy Paper Approach: Good Marketing or Good Policy? United Nation, New York and Geneva

Loewen, G (2009) A Compendium of Poverty Reduction Strategies and Frameworks, Tamarack, An Institute for Community Engagement, Waterloo, Ontario Web: www.tamarackcommunity.ca

Melbourne et al. (2004)What's Wrong With Community Building II: It's Much Worse Than We Thought,Community Development, Human Rights and the Grassroots Conference.

Mashindano, O (2009): Growth and Poverty Reduction in Tanzania: Why such a Mismatch? Policy Brief Series No.1 2009, The Economic and Social Research Foundation.

Organization for Economic Co-operation and Development -OECD (2001) The DAC Guidelines Poverty Reduction

Olofin, S et al (2011) Measuring Grassroots Perception of the Impact of Development Programs, Journal statistiqueafricain, numéro 12 13, novembre 2011, The Grassroots Focused Index (GFI)

Prato, B and Longo, R (2012) Empowerment of poor rural people through initiatives in agriculture and natural resource management, International Fund for Agricultural Development, OECD 2012

Prammer,E \& Martinuzzi, A (2013) The Millennium Development Goals (MDGs) and the Post-2015 Debate, The European Sustainable Development Network (ESDN)

Patel, P (2013): Poverty and potential: Linking grassroots innovation to inclusive development efforts in India, ProQuest, UMI Dissertations Publishing, 1553178.

Rugumamu, S (1999) Foreign Aid, Grassroots Participation and Poverty Alleviation in Tanzania: The HESAWA FIASCO, REPOA. 
Revolutionary Government of Zanzibar (2014): Zanzibar Millennium Development Goals Report, Zanzibar Planning Commission, Government Press

Revolutionary Government of Zanzibar (2010): Zanzibar Human Development Report, Government Press.

Revolutionary Government of Zanzibar (2010): MKUZA Studies, Government Press.

Revolutionary Government of Zanzibar (2010): House Budget Survey, The Office of Chief Government Statisticians, Government Press.

Revolutionary Government of Zanzibar (2010): Zanzibar Strategy for Growth and Reduction of Poverty, Government Press.

Revolutionary Government of Zanzibar (2015): Government Budget Speech, Government Press.

Revolutionary Government of Zanzibar (2009): The view of the People Report, Government Press.

Revolutionary Government of Zanzibar (2010): The MKUZA Annual Report, Government Press.

Smith, D (2009) Grassroots Associations, Springer-Verlag Berlin Heidelberg ,Boston College, Bradenton, FL, USA.

Smith, A, Fressoli, M and Thomas, H ( 2013) Grassroots innovation movements: challenges and contributions, Journal of Cleaner Production 1-11, journal homepage: www.elsevier.com/locate/jclepro

Tiwari, M (2008) Poverty and Wellbeing at the 'Grassroots'-How Much is Visible to Researchers? Springer Science+Business Media B.V

United Nation (2013): Beyond the Millennium Development Goals: The Post-2015 Sustainable Development Agenda

World Bank (2010) :Innovation Policy, A guide for developing countries, The International Bank for Reconstruction and Development 1818 H Street, NW Washington, DC 20433

World Health Organization (2008) Human Rights, Health and Poverty Reduction Strategies, • Health and Human Rights Publications Series • Issue No 5 • December 2008

World Health Organization (2005) Human Rights, Health and Poverty Reduction Strategies, Health and Human Rights Publications Series • Issue No 5 • April 2005

Worton, J (2009):"Poor" people's participation in poverty reduction, ProQuest, UMI Dissertations Publishing, MR52809. 